\title{
PERAN PENDIDIKAN TINGGI DALAM MENINGKATKAN MINAT MASYARAKAT UNTUK PRODUKTIVITAS PENDIDIKAN
}

\author{
Elfian $^{1)}$, Prasetio Ariwibowo ${ }^{2}$, Ria Susanti Johan ${ }^{3}$ \\ ${ }^{1,2,3)}$ Program Studi Pendidikan Ekonomi \\ Fakultas Ilmu Pendidikan dan Pengetahuan Sosial \\ Universitas Indraprasta PGRI Jakarta \\ Email: elfian54@gmail.com,Prasetio.ariwibowo@yahoo.com, \\ ria_johan@yahoo.com
}

\begin{abstract}
This research uses Total Quality Management method with population of selected universities in South Jakarta by limiting the problem of implementation of Total Quality Management with calculating tool using AHP (Analythical Hierarchy Proccess) as a measurement of performance and strategic management in various university civitas in South Jakarta. The TQM method is used to meet the quality requirements, quality assurance of planning and systematic that is implemented to provide sufficient confidence to the (market) community that the output of the university in satisfying the needs of the community, especially the quality in the field of higher education and become a reference policy in improving quality improvement through enhancing the effectiveness and efficiency of the processes and activities that are reflected through the organization's performance at the University. Completion of calculations in this study was conducted using Microsoft Excel 2013 program and to synthesize the influence of factors on alternative strategies using AHP Calculation 06 version 2015. Based on the results of research that has been done by the authors it can be concluded that the educational conditions, especially Higher Education is in OPTIMIS condition. This means that the predicted condition of education in Indonesia especially DKI Jakarta will experience better development than at present. The best strategic priorities in order to increase public interest in education in order to achieve the productivity of education in the future is to Improve Managerial Input Skills (Rectorate, Lecturers, Employees), Growing market / marketing, Optimizing Capital / facilities and infrastructure that has been owned by the Institute Higher Education, Higher Education set the cost affordable by various circles of society both in middle to upper middle and lower class.
\end{abstract}

Keywords: Analythical Hierarchy Process, Public Interest, Education, Productivity, Total Quality Management (TQM).

\begin{abstract}
ABSTRAK
Penelitian ini menggunakan metodeTotal Quality Management dengan populasi beberapa Universitas terpilih di Jakarta Selatan dengan membatasi masalah berupa implementasi Total Quality Managementdengan alat bantu hitung menggunakan AHP (Analythical Hierarchy Proccess) sebagai pengukuran kinerja dan manajemen strategis di berbagai civitas universitas di Jakarta Selatan.Metode TQM digunakan untuk memenuhi persyaratan kualitas, jaminan kualitas (quality assurance) perencanaan dan sistematik yang diimplemetasikan guna memberikan kepercayaan yang cukup kepada masyarakat (pasar) bahwa output dari universitas dalam memuaskan kebutuhan masyarakat khususnya kualitas di bidang pendidikan tinggi dan menjadi bahan referensi kebijakan dalam meningkatkan kualitas (quality improvement) melalui peningkatan efektivitas dan efisiensi dari proses dan aktivitas yang tercermin melalui kinerja organisasi di Universitas. Penyelesaian perhitungan dalam penelitian ini dilakukan dengan menggunakan program Microsoft Excel 2013 dan untuk mensintesa pengaruh faktor terhadap alternatif strategi dengan menggunakan Program AHP Calculation versi 06 tahun 2015. Berdasarkan hasil penelitian yang telah dilakukan oleh penulis maka dapat disimpulkan bahwa kondisi pendidikan khususnya Pendidikan Tinggi adalah dalam kondisi OPTIMIS. Hal ini berarti bahwa diperkirakan kondisi pendidikan di Indonesia khususnya DKI Jakarta akan mengalami perkembangan yang lebih baik dibandingkan saat ini. Prioritas strategi yang terbaik dalam rangka meningkatkan minat masyarakat terhadap pendidikan guna mencapai produktivitas pendidikan di masa yang akan datang adalah Meningkatkan Keterampilan Manajerial Input (Rektorat, Dosen, Karyawan), Menumbuhkan pangsa pasar/pemasaran, Mengoptimalkan Modal/sarana dan prasarana yang telah dimiliki oleh Lembaga Pendidikan Tinggi, Perguruan Tinggi menetapkan biaya terjangkau oleh berbagai kalangan masyarakat baik di kalangan menengah ke atas maupun menengah ke bawah.
\end{abstract}

Kata Kunci : Analythical Hierarchy Procces, Minat Masyarakat, Pendidikan, Produktivitas, Total Quality Management (TQM). 


\section{PENDAHULUAN}

Pendidikan merupakan kebutuhan sekunder, pendidikan tetap memiliki arti sangat penting, sebab tanpa pendidikan manusia akan sulit untuk berkembang dan bahkan menjadi golongan yang terbelakang. Dengan demikian pendidikan harus diarahkan untuk menghasilkan manusia yang berkualitas dan memiliki kompetensi yang bersaing, serta harus memiliki budi pekerti yang luhur dan moral yang baik. Empat pilar pendidikan saat ini dan masa depan yang dicanangkan oleh UNESCO yang perlu dikembangkan oleh lembaga pendidikan formal yang salah satunya adalah pendidikan tinggi, yaitu : (1) learning to know (belajar untuk mengetahui), (2) learning to do (belajar untuk melakukan sesuatu), (3) learning to be (belajar untuk menjadi seseorang), dan (4) learning to live together (belajar untuk menjalani kehidupan bersama).

Tuntutan pendidikan masa kini dan masa depan adalah peningkatan kualitas kemampuan intelektual dan profesional serta sikap, kepribadian dan moral masyarakat Indonesia pada umumnya. Dengan demikian dapat memposisikan masyarakat Indonesia secara bermartabat di masyarakat dunia di era persaingan pasar bebas saat ini.hal yang sangat mengkhawatirkan dari dunia pendidikan khususnya pendidikan tinggi pada dewasa ini adalah masih rendahnya kualitas pendidikan tinggi di Indonesia. Hal ini menurut Menteri Riset Teknologi dan Pendidikan Tinggi (Menristek Dikti) Muhammad Nasir, "Daya saing Perguruan Tinggi di Indonesia yang bisa menembus di bawah peringkat ke-500 di tingkat Internasional hanya dua Universitas. Universitas Indonesia peringkat ke-301 dan Institut Teknologi Bandung (ITB) peringkat 461-470" (http://m.monitorday.com/detail/6321/inilahpenyebab-rendahnya-kualitas-perguruan-tinggidi-Indonesia pada 20 September 2015).

Seperti halnya dengan perusahaan manufaktur lainnya, Industri Pendidikan, juga memerlukan standar Total Quality Management (TQM). Dasar pemikiran perlunya Total Quality Management diterapkan di industri pendidikan yakni bahwa cara terbaik agar pendidikan tinggi yang ada dapat bersaing dan unggul dalam persaingan global adalah dengan menghasilkan kualitas terbaik.Berdasarkan hal tersebut, penulis tertarik untuk melakukan penelitian implementasi Total Quality Management di berbagai Universitas di Jakarta Selatan dengan membatasi masalah berupa implementasi Total Quality Management dengan alat bantu hitung dengan menggunakan AHP (Analythical Hierarchy Procces) sebagai pengukuran kinerja dan manajemen strategis pendidikan tinggi dengan menggunakan populasi berbagai civitas universitas di Jakarta Selatan.

Menurut UU RI No. 20 Tahun 2003 Pasal 1 Tentang Sistem Pendidikan nasional, Pendidikan merupakan usaha sadar dan terencana untuk mewujudkan suasana belajar dan proses pembelajaran agar peserta didik secara aktif mengembangkan potensi dirinya untuk memiliki kekuatan spiritual keagamaan, pengendalian diri, kepribadian, kecerdasan, akhlak mulia, serta keterampilan yang diperlukan dirinya, masyarakat, bangsa dan negara.

Dasar Pendidikan adalah pondasi atau landasan yang kokoh bagi setiap masyarakat untuk dapat melakukan perubahan sikap dan tata laku dengan cara berlatih dan belajar dan tidak terbatas pada lingkungan lembaga pendidikan. Dasar atau landasan pendidikan dilihat dari berbagai segi, antara lain :

a. Religius

Merupakan elemen atau dasar pendidikan yang paling pokok yang ditanamkan nilainilai agama islam (iman, akidah, dan akhlak) sebagai suatu pondasi yang kokoh dalam pendidikan

b. Ideologis

Yaitu landasan yang mengacu pada ideologis bangsa yaitu pancasila dan UUD 1945. Dan intinya adalah untuk mencerdaskan kehidupan bangsa.

c. Ekonomi

Pendidikan bisa dijadikan sebagai suatu langkah untuk mendapatkan kehidupan yang layak dan keluar dari segala bentuk kebodohan dan kemiskinan

d. Politik

Lebih mengacu pada kondisi yang sedang berlangsung

e. Teknologi

Dunia telah mengalami eksplosit ilmu pengetahuan dan teknologi. Dan bisa dikatakan teknologi sangat memiliki peran dalam kemajuan dunia pendidikan

f. Psikologis dan Pedagogis

Tugas pendidikan adalah mengajarkan bagaimana cara belajar, mendidik kejiwaan, menanamkan motivasi yang kuat dalam diri siswa/i ajar untuk belajar terus menerus sepanjang hidupnya dan memberikan 
keterampilan kepada peserta didik, mengembangkan daya adaptasi yang besar dalam diri peserta didik.

Menurut Soekidjo Notoatmodjo (2003:16), unsur-unsur pendidikan terdiri dari :

a. Input

Sasaran pendidikan, yaitu : individu, kelompok, masyarakat

b. Pendidik, yaitu pelaku pendidikan

c. Proses

Yaitu upaya yang direncanakan untuk mempengaruhi orang lain

d. Output

Yaitu melakukan apa yang diharapkan/perilaku

Menurut UU RI No. 20 Tahun 2003, jalur pendidikan dibagi menjadi :

\section{Jalur Formal}

a. Pendidikan Dasar

Pendidikan dasar berbentuk Sekolah Dasar (SD) dan Madrasah Ibtidaiyah atau bentuk lain yang sederajat serta Sekolah Menengah Pertama (SMP) dan Madrasah Tsanawiyah (MTs) atau bentuk lain yang sederajat.

b. Pendidikan Menengah

Pendidikan menengah terdiri atas pendidikan menengah umum dan pendidikan menengah jurusan, seperti : SMA, MA, SMK, MAK, atau bentuk lain yang sederajat.

c. Pendidikan Tinggi

Pendidikan tinggi dapat berbentuk akademi, politeknik, sekolah tinggi, institut, dan universitas

\section{Jalur Non Formal}

Pendidikan informal adalah proses yang berlangsung sepanjang usia sehingga setiap orang memperoleh nilai, sikap, keterampilan, dan pengetahuan yang bersumber dari pengalaman hidup sehari-hari, pengaruh lingkungan termasuk di dalamnya adalah pengaruh kehidupan keluarga, hubungan dengan tetangga, lingkungan pekerjaan dan permainan, pasar, perpustakaan, dan media massa.

\section{Jalur Informal}

Pendidikan informal adalah proses yang berlangsung sepanjang usia sehingga setiap orang memperoleh nilai, sikap, keterampilan, dan pengetahuan yang bersumber dari pengalaman hidup sehari-hari, pengaruh lingkungan termasuk di dalamnya adalah pengaruh kehidupan keluarga, hubungan dengan tetangga, lingkungan pekerjaan dan permainan, pasar, perpustakaan, dan media massa.
Guna mendukung latar belakang penelitian, penulis menggunakan beberapa penelitian yang relevan sebagai pedoman penulis dalam menuyusun dan membahas dari penelitian penulis, antara lain :

1. Soni A. Nulhaqim, Dudi Heryadi, dan Ramadhan Pancasilawan (2014)

Soni, Dudi, dan Ramadhan merupakan dosen FISIP Universitas Padjajaran Bandung melakukan penelitian di tahun 2014 berjudul "Peranan Perguruan Tinggi Dalam Meningkatkan Kualitas Pendidikan di Indonesia Untuk Menghadapi ASEAN Community 2015 (Studi Kasus Universitas Padjajaran) dan menghasilkan pemikiran dari hasil penelitian nya berupa ASEAN Community 2015 dihadapi oleh Masyarakat Indonesia. Perguruan Tinggi memiliki kontribusi yang besar dalam meningkatkan kualitas Sumber Daya Manusia (SDM). Berkenaan hal tersebut, Unpad sebagai salah satu perguruan tinggi besar di Indonesia yang berada di daerah dan lahir atas kehendak masyarakat dan tokoh Jawa Barat tahun 1957. Pertanyaannya, Bagaimana peranan Unpad sebagai perguruan Tinggi dalam meningkatkan kualitas pendidikan untuk menghadapi ASEAN Community? Teori yang digunakan untuk mengkaji tema penelitian ini menggunakan perspektif Kesejahteraan Sosial khususnya Teori Pembangunan Sosial dan perspektif Hubungan Internasional dengan Teori Epistemic Community.

Metode penelitiannya adalah kualitatif dengan teknik studi kasus. Sumber data meliputi data primer melalui Indepth Interview maupun sekunder dengan analisis deskriptif. Temuan Penelitian, Unpad sebagai Perguruan Tinggi mengalami perubahan bentuk mulai dari Perguruan Tinggi Negeri, kemudian PTN Badan Layanan Umum (2008) dan Transisi menuju PTN Berbadan Hukum (2014). Capaian Unpad meliputi Akreditasi A Institusi Perguruan Tinggi, Tiga tahun berturut sebagai PT yang paling banyak diminati oleh calon mahasiswa melalui Seleksi Nasional Masuk PTN, dan Wajib Tanpa Pengecualian (WTP) hasil audit Keuangan. Upaya Unpad dalam menuju ASEAN Community ditunjukkan melalui Komitmen dalam Rencana Strategisnya yaitu Menjadi Universitas Unggul dalam Penyelenggaraan Pendidikan Tinggi Kelas Dunia, Penguatan Infrastruktur melaui Sistem pelayanan berbasis IT, Memiliki lima pilar penelitian yang didukung oleh sumber dana yang cenderung meningkat dan hasil penelitian berbasis produk, 
Peningkatan Kualitas SDM melalui Studi lanjut program doktor ke Luar Negeri serta wacana Dosen Riset, Tata kelola Kerja sama dan jejaring kerja sama yang baik, Keberadaan mahasiswa Asing yang cenderung meningkat, kecenderungan semakin terintegrasinya, hasil penelitian menjadi dasar dalam proses pendidikan, dan pengabdian kepada masyarakat.

Unpad sebagai Perguruan Tinggi mengalami perubahan bentuk mulai dari Perguruan Tinggi Negeri, kemudian PTN Badan Layanan Umum (2008) dan Transisi menuju PTN Berbadan Hukum (2014). Capaian Unpad meliputi Akreditasi A Institusi Perguruan Tinggi, Tiga tahun berturut sebagai PT yang paling banyak diminati oleh calon mahasiswa melalui Seleksi Nasional Masuk PTN dan SBMPTN, hasil audit keuangan Unpad Wajib Tanpa Pengecualian (WTP). 23 Unpad dalam menuju ASEAN Community ditunjukan melalui Komitmen dalam Rencana Strategisnya yaitu Menjadi Universitas Unggul dalam Penyelenggaraan Pendidikan Tinggi Kelas Dunia, meliputi 1) Periode tahun 2007- 2011 : menjadi universitas pembelajaran unggul (excellent teaching university); 2) Periode tahun 2012-2016 : menjadi universitas riset dan pelayanan bermutu (research and excellent teaching university); 3) Periode tahun 20172021 : menjadi universitas berdaya saing regional (regional class university); dan 4) Periode tahun 2022-2026 : menjadi universitas berdaya saing internasional (entreprenerial world-class university). Penguatan Infrastruktur berbasis IT dalam pelayanan pengajaran, penelitian dan pengabdian kepada masyarakat. Penelitian memiliki lima pilar yaitu: kesehatan, pangan, energi, lingkungan, dan kebijakan, yang didukung oleh sumber dana yang cenderung meningkat dan hasil penelitian berbasis produk. Pengabdian kepada masyarakat berbentuk KKNintegratif dengan tema belajar dari masyarakat dan karya inovasi yang sesuai dengan kebutuhan masyarakat. Dalam bidang pengajaran, Universitas Padjadjaran saat ini memberikan layanan pengajaran yang terbaik dan memfokuskan pada pengembangan riset. Kebijakan dalam pengembangan kurikulum mengacu pada Kurikulum Perguruan Tinggi (KPT). Dalam meningkatkan kualitas pengajaran, Unpad memberikan pelatihan kepada tenaga pendidik untuk peningkatan kapasitas pengajaran baik di dalam negeri maupun di luar negeri seperti: Pekerti, AA, SAME (Scheme for Academic Mobility and
Exchange), benchmarking dan program pelatihan lainnya serta mengkuti studi lanjut program doktor ke luar negeri. Kemudian dalam bidang pengajaran, Unpad menerapkan insentif berbasis kinerja kepada para dosennya. Dalam Tata kelola kerja sama yang dilakukan Unpad dibentuk Unit Pelaksana Teknis Kerja Sama Universitas Padjadjaran. UPT tersebut berfungsi untuk koordinasi pelaksanaan program kerja sama nasional dan internasional, pengendalian program kerjasama nasional dan internasional, serta evaluasi dan pelaporan program kerjasama. Bentuk kerja sama Unpad bisa dilihat dari bertambahnya jumlah mahasiswa Asing di Unpad. Data terakhir jumlah mahasiswa asing di Unpad mencapai 1.083 mahasiswa

\section{Linda Setiawati (2010)}

Linda Setiawati merupakan dosen Universitas Pendidikan Indonesia (UPI) Bandung yang melakukan penelitian di tahun 2010 berjudul "Efektivitas Pengembangan Manajemen Pendidikan Tinggi (Studi pada Perguruan Tinggi Negeri di Jawa Barat Menuju World Class University)". Penelitian beliau bertujuan untuk mendeskripsikan dan menganalisis efektivitas pengembangan manajemen pendidikan terutama proses perencanaan, pelaksanaan dan pengawasan PTN di Jawa Barat; mengidentifikasi dan menganalisis indikator kriteria perankingan universitas kelas dunia yang dilakukan THES, SJTU dan Webometric yang telah dicapai oleh PTN di Jawa Barat; Mendeskripsikan dan mengindentifikasi model manajemen pendidikan tinggi dilihat dari aspek interal service quality, service capability serta eksternal service quality yang di terapkan oleh PTN di Jawa Barat. Metode penelitian yang digunakan adalah deskriptif analisis. Teknik pengumpulan data yang dilakukan adalah studi literatur dan studi lapangan. Studi lapangan menggunakan wawancara dan observasi. Sumber data dari 6 (enam) PTN di Jawa Barat, yaitu UI, ITB, IPB, UNPAD, UPI, UIN. Hasil penelitian menunjukkan bahwa dalam pengembangan manajemen pendidikan tinggi dilihat dari fungsi manajemen pendidikan, proses perencanaan dan pengawasan telah dilakukan dengan baik, sedangkan proses pelaksanaan belum memadai; dalam perangkingan universitas dunia, belum ada satu pun PTN di Jawa Barat yang masuk ke dalam dengan kriteria THES dan SJTU. Berdasarkan pemeringkatan versi webometric Juli 2012, 5 (lima) PTN di Jawa Barat masuk ke 
dalam 1000 universitas top dunia, UI berada di peringkat peringkat 507 dan ITB berada dalam peringkat 568, UPI berada di peringkat 630, IPB berada di peringkat peringkat 764, dan UNPAD berada di peringkat peringkat 990 ranking dunia; dilihat dari model pengembangan manajemen pendidikan tinggi berdasarkan aspek internal service quality, service capability serta eksternal service quality, PTN di Jawa Barat mengembangkan manajemen pendidikan tinggi disesuaikan dengan kekhasan masing-masing perguruan tinggi. Internal service quality dan eksternal service quality merupakan aspek yang sudah dapat dipenuhi oleh masing-masing PTN, sedangkan service capability merupakan aspek yang membutuhkan perhatian lebih banyak

\section{METODE}

\section{Total Quality Management}

Manajemen kualitas terpadu (Total Quality Management $=$ TQM) adalah suatu cara meningkatkan performansi secara terus menerus (continuous performance improvement) pada setiap level operasi atau proses, dalam setiap area fungsional dari suatu organisasi, dengan menggunakan sumber daya manusia dan modal yang tersedia. Dalam ISO 8402(Quality Vocabulary) mendefinisikan manajemen kualitas sebagai semua aktivitas dari fungsi manajemen secara keseluruhan yang menentukan kebijakan kualitas, tujuan-tujuan dan tanggung jawab, serta mengimplikasikannya melalui alat-alat seperti perencanaan kualitas (quality planning) yaitu penetapan dan pengembangan tujuan dan kebutuhan untuk kualitas serta penerapan sistem kualitas; pengendalian kualitas (quality control) adalah teknik-teknik dan aktivitas operasional yang digunakan untuk memenuhi persyaratan kualitas; jaminan kualitas (quality assurance) adalah semua tindakan terencana dan sistematik yang diimplemetasikan dan didemonstrasikan guna memberikan kepercayaan yang cukup bahwa produk akan memuaskan kebutuhan untuk kualitas tertentu; dan peningkatan kualitas (quality improvement) yaitu tindakan-tindakan yang diambil guna meningkatkan nilai produk untuk pelanggan melalui peningkatan efektivitas dan efisiensi dari proses dan aktivitas melalui struktur organisasi.

\section{Analytical Hierarchy Process}

Ciri pemecahan model AHP adalah menggunakan hirarki yang menguraikan permasalahan yang kompleks menjadi elemenelemen yang lebih sederhana. Hirarki dari metode ini dapat dibagi menjadi Goal, Skenario, Sasaran, dan Strategi. Menurut Saaty (1993), hirarki didefinisikan sebagai suatu representasi dari sebuah permasalahan yang kompleks dalam suatu struktur multi level dimana level pertama adalah tujuan, yang diikuti level faktor, kriteria, sub kriteria, dan seterusnya ke bawah hingga level terakhir dari alternatif. Dalam penelitian ini, hirarki yang akan digunakan dalam menentukan kebijakan membangunan daerah yang terbaik adalah hirarki yang terdapat pada diagram 3.1

GOAL
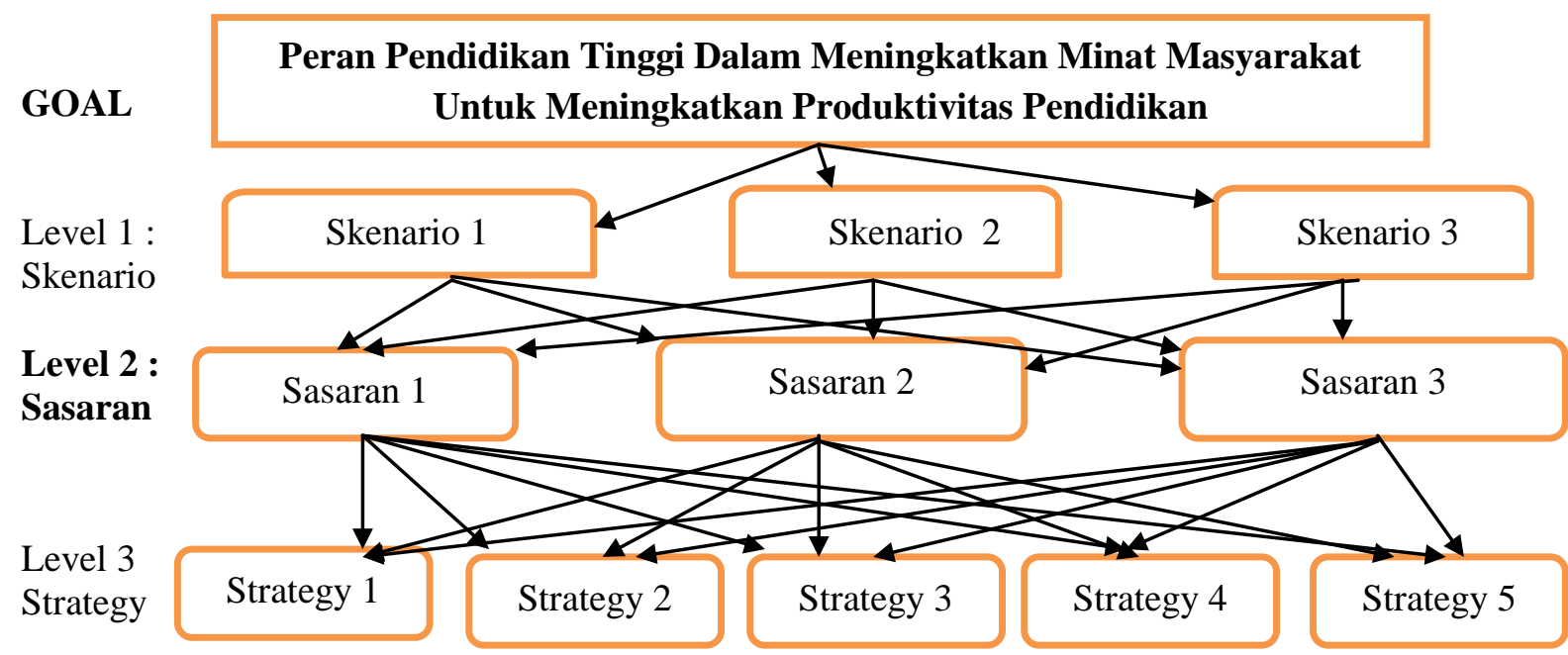

Gambar 1.1 Penyusunan Hirarki Model AHP 
Keterangan :

I. Level 1 :

Skenario 1 : Optimis

Skenario 2 : Status Quo (Ragu-ragu)

Skenario 3 : Pesimis

II. Level 2 :

Sasaran 1 : Meningkatkan Kualitas Output (Wisudawan/wati)

Sasaran 2 : Meningkatkan Sarana dan

Prasarana Kegiatan Belajar Mengajar

(Gedung, Lahan Parkir, Laboratorium, dll.)

Sasaran 3 : Meningkatkan Pendapatan/Profit

Lembaga Pendidikan Tinggi

III. Level 3 :

Strategi 1 : Meningkatkan Keterampilan

Manajerial Input (Rektorat, Dosen, Karyawan)
Strategi 2: Menumbuhkan pangsa

pasar/pemasaran

Strategi 3 : Biaya yang Terjangkau

Strategi 4 : Mengoptimalkan Modal/sarana dan prasarana yang telah dimiliki oleh Lembaga

Pendidikan Tinggi

Penentuan jumlah expert yang disyaratkan sebagai orang yang benar-benar menguasai permasalahan bisa saja memberikan hasil yang lebih baik daripada penilaian banyak responden yang tidak terlalu memahami permasalahan. Pada penelitian ini, para ahli yang diminta untuk menjadi responden kuisioner AHP sebanyak 15 orang, yaitu, Pejabat lembaga pendidikan tinggi, Dosen, dan mahasiswa yang masih aktif di 3 (tiga) Universitas di Jakarta Selatan yang telah dipilih oleh penulis.

Tabel 1.1 Tabel Responden Penelitian

\begin{tabular}{clll}
\hline No & \multicolumn{1}{c}{ Instansi } & \multicolumn{1}{c}{ Jabatan Struktural } & \multicolumn{1}{c}{ Jabatan Fungsional } \\
\hline 1 & Universitas Nasional & Kepala Bagian LPPM & Lektor Kepala \\
\hline 2 & Universitas Nasional & Ketua LPPM UNAS & Lektor Kepala \\
\hline 3 & Universitas Nasional & Ka. Lab. Mikrobiologi UNAS & Lektor Kepala \\
\hline 4 & Universitas Nasional & Ka. Prodi Pascasarjana Biologi UNAS & Lektor Kepala \\
\hline 5 & Universitas Nasional & Dosen Fakultas Pertanian UNAS & Lektor Kepala \\
\hline 6 & Universitas Pancasila & Ka. Bagian LPPM Univ. Pancasila & Lektor \\
\hline 7. & Universitas Pancasila & Wakil Ketua LPPM Univ. Pancasila & Lektor \\
\hline 8 & Universitas Pancasila & Ketua LP3 Univ. Pancasila (Rektorat) & Guru Besar \\
\hline 9 & Universitas Pancasila & Ketua LPPM Universitas Pancasila & Lektor \\
\hline 10 & Universitas Pancasila & Ketua KJM & Lektor \\
\hline 11 & Universitas Pancasila & Kabag. Penelitian LPPM Univ. Pancasila & Lektor \\
\hline 12 & Univ. Al-Azhar Indonesia & Ketua LPPM Univ. Al-Azhar Indonesia & Lektor Kepala \\
\hline 13 & Univ. Al-Azhar Indonesia & Mahasiswa & Mahasiswa Semester \\
\hline \multirow{2}{*}{14} & Univ. Al-Azhar Indonesia & Mahasiswi & VIII \\
\hline \multirow{2}{*}{15} & \multirow{2}{*}{ Univ. Al-Azhar Indonesia } & Mahasiswi & Vahasiswi Semester \\
& & & Mahasiswi Semester \\
\hline
\end{tabular}

Penyelesaian perhitungan dilakukan dengan menggunakan program Microsoft Excel 2013 dan untuk mensintesa pengaruh faktor terhadap alternatif strategi dengan menggunakan Program AHP Calculation 06 version 2015.

\section{HASIL DAN PEMBAHASAN}

Berdasarkan kuesioner yang telah diisi oleh responden dari berbagai Universitas yang sebagai sampel bagi penulis, maka penulis melakukan pengolahan data, sehingga diha silkan nilai konsensus seperti yang dapat dijelaskan pada tabel 1.2. 
Tabel 1.2 Hasil Penghitungan AHP atas Penilaian Responden

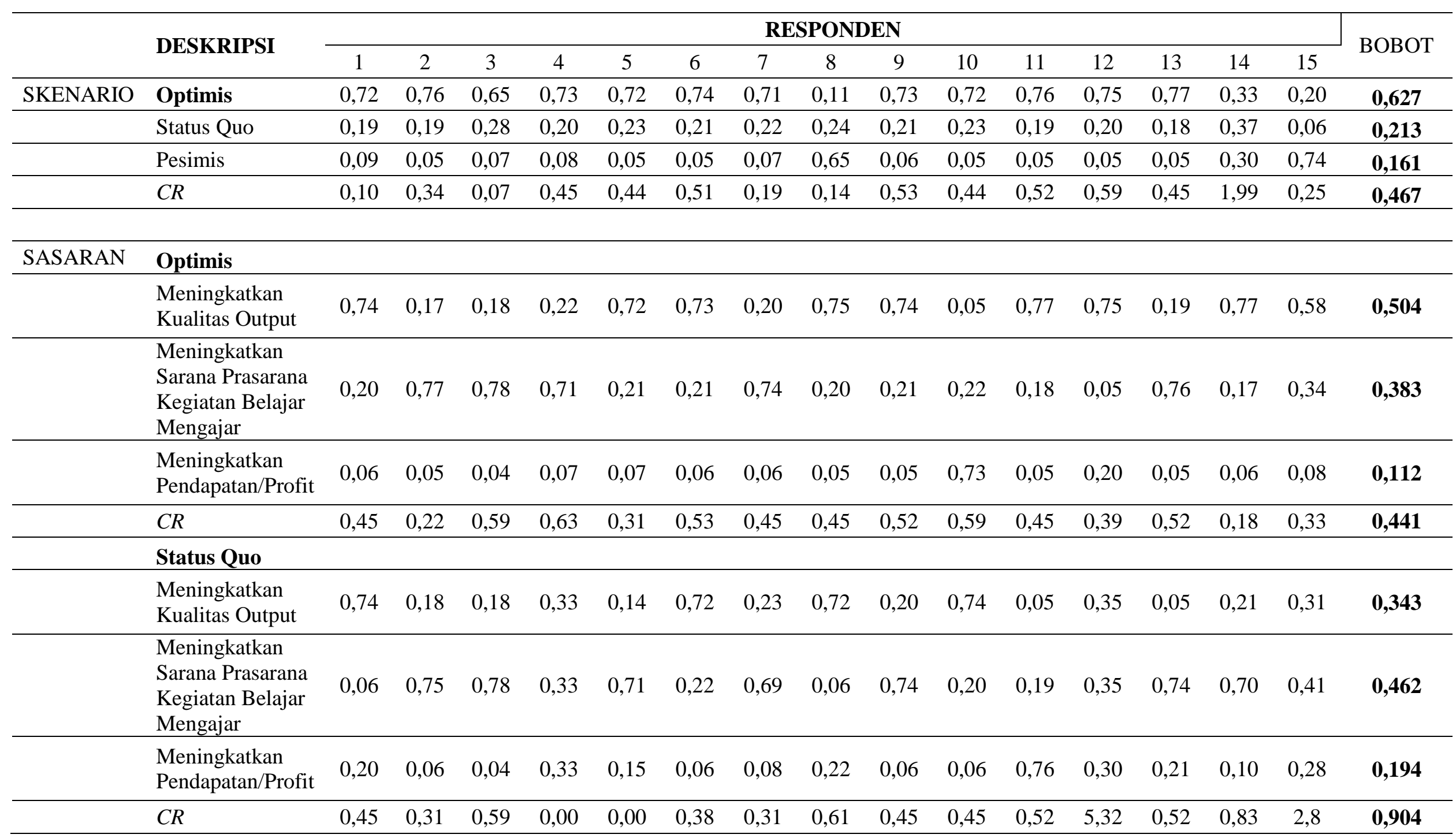




\section{Pesimis}

Meningkatka

Kualitas Output

0,90

Meningkatkan

Sarana Prasarana

Kegiatan Belajar

$0,22 \quad 0,38 \quad 0,90$

$0,90 \quad 0,20$

0,70

0,73

0,73

0,05

0,76

0,74

0,33

0,77

$0,05 \quad 0,24 \quad 0,65$

0,524

Mengajar

Pendapatan/Profit

CR

\begin{tabular}{|c|c|c|c|c|c|c|c|c|c|c|c|c|c|c|c|c|}
\hline $\begin{array}{l}\text { Meningkatkan } \\
\text { Pendapatan/Profit }\end{array}$ & 0,70 & 0,32 & 0,81 & 0,74 & 0,68 & 0,70 & 0,70 & 0,20 & 0,19 & 0,50 & 0,33 & 0,18 & 0,77 & 0,35 & 0,22 & 0,493 \\
\hline$C R$ & 0,63 & 5,94 & 0,00 & 0,45 & 0,38 & 0,45 & 0,45 & 0,39 & 0,52 & 0,51 & 6,39 & 0,45 & 0,45 & 1,79 & 0,31 & 1,27 \\
\hline
\end{tabular}

$0,60 \quad 0,25 \quad 0$

$20 \quad 0$,

$20 \quad 0,7$

$75 \quad 0,50 \quad 0$

210,3

\section{STRATEGI}

\section{Optimis}

\section{Meningkatkan}

Kualitas Output

\begin{tabular}{|c|c|c|c|c|c|c|c|c|c|c|c|c|c|c|c|c|}
\hline $\begin{array}{l}\text { Meningkatkan } \\
\text { Keterampilan } \\
\text { Manajerial Input }\end{array}$ & 0,63 & 0,30 & 0,47 & 0,23 & 0,53 & 0,61 & 0,63 & 0,30 & 0,62 & 0,64 & 0,03 & 0,72 & 0,64 & 0,61 & 0,64 & 0,507 \\
\hline $\begin{array}{l}\text { Menumbuhkan } \\
\text { Pangsa } \\
\text { Pasar/Pemasaran }\end{array}$ & 0,24 & 0,05 & 0,04 & 0,03 & 0,12 & 0,13 & 0,24 & 0,35 & 0,03 & 0,25 & 0,64 & 0,10 & 0,03 & 0,18 & 0,09 & 0,168 \\
\hline $\begin{array}{l}\text { Biaya yang } \\
\text { Terjangkau }\end{array}$ & 0,09 & 0,05 & 0,07 & 0,09 & 0,05 & 0,20 & 0,09 & 0,04 & 0,26 & 0,03 & 0,09 & 0,09 & 0,09 & 0,06 & 0,15 & $\mathbf{0 , 0 9 7}$ \\
\hline $\begin{array}{l}\text { Mengoptimalkan } \\
\text { Sarana dan } \\
\text { Prasarana yang } \\
\text { dimiliki Perguruan } \\
\text { Tinggi }\end{array}$ & 0,03 & 0,60 & 0,41 & 0,63 & 0,29 & 0,06 & 0,03 & 0,31 & 0,09 & 0,08 & 0,23 & 0,09 & 0,23 & 0,16 & 0,12 & 0,224 \\
\hline$C R$ & 0,38 & 0,24 & 0,04 & 0,49 & 0,21 & 0,32 & 0,38 & 1,79 & 0,36 & 0,40 & 0,38 & 0,56 & 0,36 & 0,25 & 0,23 & $\mathbf{0 , 4 3}$ \\
\hline
\end{tabular}




\begin{tabular}{|c|c|c|c|c|c|c|c|c|c|c|c|c|c|c|c|c|}
\hline $\begin{array}{l}\text { Meningkatkan } \\
\text { Sarana Prasarana } \\
\text { Kegiatan Belajar } \\
\text { Mengajar }\end{array}$ & & & & & & & & & & & & & & & & \\
\hline $\begin{array}{l}\text { Menumbuhkan } \\
\text { Pangsa } \\
\text { Pasar/Pemasaran }\end{array}$ & 0,26 & 0,70 & 0,030 & 0,030 & 0,300 & 0,060 & 0,700 & 0,100 & 0,370 & 0,35 & 0,03 & 0,06 & 0,30 & 0,18 & 0,23 & 0,247 \\
\hline $\begin{array}{l}\text { Biaya yang } \\
\text { Terjangkau }\end{array}$ & 0,11 & 0,06 & 0,070 & 0,080 & 0,310 & 0,290 & 0,100 & 0,100 & 0,140 & 0,37 & 0,64 & 0,33 & 0,31 & 0,06 & 0,07 & 0,203 \\
\hline $\begin{array}{l}\text { Mengoptimalkan } \\
\text { Sarana dan } \\
\text { Prasarana yang } \\
\text { dimiliki Perguruan } \\
\text { Tinggi }\end{array}$ & 0,04 & 0,16 & 0,680 & 0,680 & 0,060 & 0,310 & 0,100 & 0,100 & 0,130 & 0,13 & 0,08 & 0,31 & 0,04 & 0,16 & 0,12 & 0,207 \\
\hline$C R$ & 0,45 & 0,48 & 0,43 & 0,43 & 0,88 & 1,09 & 0,57 & 0,57 & 2,24 & 2,43 & 0,42 & 1,78 & 1,80 & 0,25 & 0,36 & 0,95 \\
\hline $\begin{array}{l}\text { Meningkatkan } \\
\text { Pendapatan/Profit }\end{array}$ & & & & & & & & & & & & & & & & \\
\hline $\begin{array}{l}\text { Meningkatkan } \\
\text { Keterampilan } \\
\text { Manajerial Input }\end{array}$ & 0,15 & 0,15 & 0,04 & 0,04 & 0,61 & 0,63 & 0,09 & 0,27 & 0,64 & 0,09 & 0,04 & 0,65 & 0,64 & 0,10 & 0,04 & 0,279 \\
\hline $\begin{array}{l}\text { Menumbuhkan } \\
\text { Pangsa } \\
\text { Pasar/Pemasaran }\end{array}$ & 0,36 & 0,65 & 0,64 & 0,68 & 0,26 & 0,21 & 0,24 & 0,61 & 0,23 & 0,65 & 0,25 & 0,24 & 0,24 & 0,05 & 0,14 & 0,363 \\
\hline $\begin{array}{l}\text { Biaya yang } \\
\text { Terjangkau }\end{array}$ & 0,36 & 0,04 & 0,10 & 0,19 & 0,10 & 0,12 & 0,03 & 0,03 & 0,03 & 0,03 & 0,09 & 0,03 & 0,03 & 0,22 & 0,57 & 0,131 \\
\hline $\begin{array}{l}\text { Mengoptimalkan } \\
\text { Sarana dan } \\
\text { Prasarana yang } \\
\text { dimiliki Perguruan } \\
\text { Tinggi }\end{array}$ & 0,13 & 0,17 & 0,23 & 0,08 & 0,04 & 0,05 & 0,63 & 0,09 & 0,10 & 0,23 & 0,62 & 0,08 & 0,09 & 0,62 & 0,24 & 0,227 \\
\hline
\end{tabular}




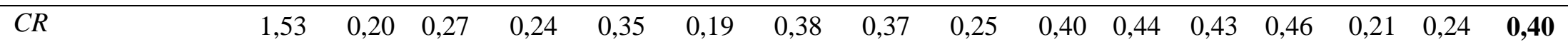

\section{STATUS QUO}

\section{Meningkatkan Kualitas Output}

$\begin{array}{lllllllllllllllll}\text { Meningkatkan Keterampilan } & 0,58 & 0,35 & 0,14 & 0,16 & 0,58 & 0,63 & 0,09 & 0,37 & 0,64 & 0,14 & 0,66 & 0,65 & 0,14 & 0,30 & 0,47 & \mathbf{0 , 3 9 3}\end{array}$

Manajerial Input

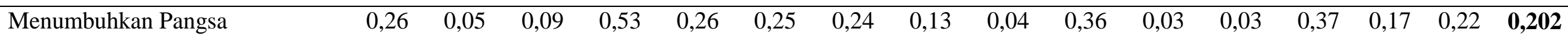

Pasar/Pemasaran

Biaya yang Terjangkau

\begin{tabular}{llllllllllllllll}
0,12 & 0,27 & 0,55 & 0,26 & 0,05 & 0,09 & 0,03 & 0,14 & 0,23 & 0,37 & 0,22 & 0,09 & 0,36 & 0,34 & 0,07 & $\mathbf{0 , 2 1 3}$ \\
\hline
\end{tabular}

Mengoptimalkan Sarana dan

Prasarana yang dimiliki

Perguruan Tinggi

\begin{tabular}{|c|c|c|c|c|c|c|c|c|c|c|c|c|c|c|c|c|}
\hline$C R$ & 0,25 & 1,56 & 0,06 & 0,23 & 0,23 & 0,27 & 0,38 & 2,24 & 0,44 & 2,29 & 0,36 & 0,30 & 2,60 & 1,04 & 0,03 & 0,82 \\
\hline \multicolumn{17}{|l|}{$\begin{array}{l}\text { Meningkatkan Sarana } \\
\text { Prasarana Kegiatan Belajar } \\
\text { Mengajar }\end{array}$} \\
\hline $\begin{array}{l}\text { Meningkatkan Keterampilan } \\
\text { Manajerial Input }\end{array}$ & 0,57 & 0,23 & 0,43 & 0,170 & 0,61 & 0,62 & 0,24 & 0,04 & 0,04 & 0,37 & 0,65 & 0,04 & 0,05 & 0,12 & 0,06 & 0,283 \\
\hline $\begin{array}{l}\text { Menumbuhkan Pangsa } \\
\text { Pasar/Pemasaran }\end{array}$ & 0,28 & 0,03 & 0,24 & 0,39 & 0,24 & 0,25 & 0,6 & 0,64 & 0,63 & 0,12 & 0,24 & 0,65 & 0,33 & 0,58 & 0,14 & $\mathbf{0 , 3 5 7}$ \\
\hline Biaya yang Terjangkau & 0,11 & 0,09 & 0,270 & 0,33 & 0,11 & 0,09 & 0,04 & 0,23 & 0,24 & 0,23 & 0,08 & 0,230 & 0,310 & 0,15 & 0,49 & $\mathbf{0 , 2 0 0}$ \\
\hline $\begin{array}{l}\text { Mengoptimalkan Sarana dan } \\
\text { Prasarana yang dimiliki } \\
\text { Perguruan Tinggi }\end{array}$ & 0,05 & 0,65 & 0,06 & 0,11 & 0,05 & 0,04 & 0,12 & 0,09 & 0,09 & 0,38 & 0,03 & 0,09 & 0,31 & 0,15 & 0,31 & 0,169 \\
\hline
\end{tabular}




\begin{tabular}{|c|c|c|c|c|c|c|c|c|c|c|c|c|c|c|c|c|}
\hline$C R$ & 0,28 & 0,25 & 0,15 & 0,09 & 0,28 & 0,42 & 0,41 & 0,38 & 0,38 & 2,21 & 0,45 & 0,44 & 2,02 & 0,48 & 0,20 & 0,56 \\
\hline \multicolumn{17}{|l|}{$\begin{array}{l}\text { Meningkatkan } \\
\text { Pendapatan/Profit }\end{array}$} \\
\hline $\begin{array}{l}\text { Meningkatkan Keterampilan } \\
\text { Manajerial Input }\end{array}$ & 0,64 & 0,03 & 0,30 & 0,23 & 0,62 & 0,63 & 0,04 & 0,30 & 0,14 & 0,37 & 0,09 & 0,64 & 0,64 & 0,28 & 0,30 & $\mathbf{0 , 3 5 0}$ \\
\hline $\begin{array}{l}\text { Menumbuhkan Pangsa } \\
\text { Pasar/Pemasaran }\end{array}$ & 0,22 & 0,69 & 0,17 & 0,40 & 0,23 & 0,25 & 0,58 & 0,32 & 0,14 & 0,35 & 0,65 & 0,25 & 0,09 & 0,26 & 0,16 & $\mathbf{0 , 3 1 7}$ \\
\hline Biaya yang Terjangkau & 0,10 & 0,08 & 0,13 & 0,23 & 0,10 & 0,09 & 0,12 & 0,05 & 0,35 & 0,14 & 0,23 & 0,03 & 0,03 & 0,08 & 0,13 & $\mathbf{0 , 1 2 6}$ \\
\hline $\begin{array}{l}\text { Mengoptimalkan Sarana dan } \\
\text { Prasarana yang dimiliki } \\
\text { Perguruan Tinggi }\end{array}$ & 0,03 & 0,20 & 0,39 & 0,13 & 0,05 & 0,03 & 0,26 & 0,33 & 0,38 & 0,14 & 0,03 & 0,08 & 0,24 & 0,38 & 0,40 & 0,205 \\
\hline$C R$ & 0,31 & 0,38 & 0,05 & 0,11 & 0,25 & 0,41 & 0,25 & 1,90 & 2,39 & 2,46 & 0,43 & 0,40 & 0,46 & 0,69 & 1,06 & 0,77 \\
\hline
\end{tabular}

\section{PESIMIS}

\section{Meningkatkan Kualitas Output}

Meningkatkan Keterampilan

Manajerial Input

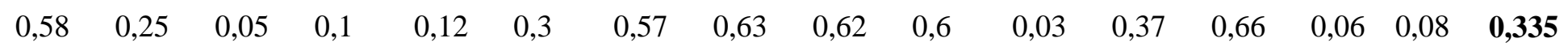

\begin{tabular}{|c|c|c|c|c|c|c|c|c|c|c|c|c|c|c|c|c|}
\hline $\begin{array}{l}\text { Menumbuhkan Pangsa } \\
\text { Pasar/Pemasaran }\end{array}$ & 0,28 & 0,03 & 0,33 & 0,25 & 0,26 & 0,35 & 0,27 & 0,04 & 0,25 & 0,04 & 0,64 & 0,13 & 0,03 & 0,26 & 0,14 & 0,220 \\
\hline Biaya yang Terjangkau & 0,11 & 0,66 & 0,44 & 0,43 & 0,05 & 0,31 & 0,12 & 0,24 & 0,03 & 0,26 & 0,10 & 0,14 & 0,23 & 0,52 & 0,40 & 0,269 \\
\hline $\begin{array}{l}\text { Menoptimalkan Sarana dan } \\
\text { Prasarana yang dimiliki } \\
\text { Perguruan Tinggi }\end{array}$ & 0,04 & 0,07 & 0,18 & 0,22 & 0,58 & 0,04 & 0,05 & 0,09 & 0,09 & 0,1 & 0,23 & 0,36 & 0,08 & 0,16 & 0,38 & $\mathbf{0 , 1 7 8}$ \\
\hline$C R$ & 0,31 & 0,34 & 0,19 & 0,27 & 0,25 & 1,11 & 0,28 & 0,38 & 0,33 & 0,38 & 0,34 & 2,60 & 0,40 & 0,30 & 0,11 & 0,51 \\
\hline
\end{tabular}


Meningkatkan Sarana

Prasarana Kegiatan Belajar

Mengajar

Meningkatkan Keterampilan

Manajerial Input

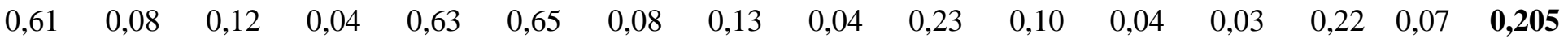

Menumbuhkan Pangsa

Pasar/Pemasaran

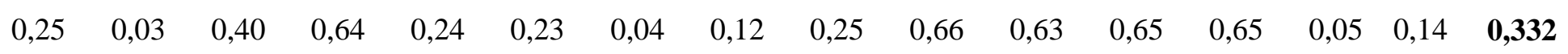

Biaya yang Terjangkau

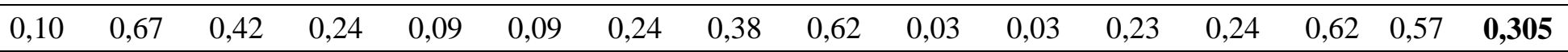

Mengoptimalkan Sarana dan

Prasarana yang dimiliki

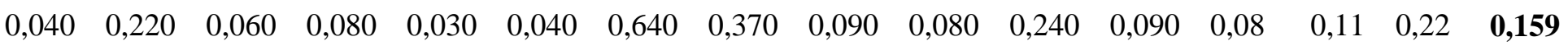

Perguruan Tinggi

\begin{tabular}{|c|c|c|c|c|c|c|c|c|c|c|c|c|c|c|c|c|}
\hline$C R$ & 0,45 & 0,47 & 0,15 & 0,34 & 0,38 & 0,29 & 0,34 & 2,29 & 0,44 & 0,43 & 0,38 & 0,43 & 0,46 & 0,12 & 0,22 & 0,48 \\
\hline \multicolumn{17}{|l|}{$\begin{array}{l}\text { Meningkatkan } \\
\text { Pendapatan/Profit }\end{array}$} \\
\hline $\begin{array}{l}\text { Meningkatkan Keterampilan } \\
\text { Manajerial Input }\end{array}$ & 0,65 & 0,03 & 0,16 & 0,16 & 0,61 & 0,64 & 0,08 & 0,09 & 0,69 & 0,10 & 0,66 & 0,10 & 0,14 & 0,06 & 0,05 & 0,281 \\
\hline $\begin{array}{l}\text { Menumbuhkan Pangsa } \\
\text { Pasar/Pemasaran }\end{array}$ & 0,21 & 0,08 & 0,08 & 0,08 & 0,25 & 0,24 & 0,04 & 0,71 & 0,10 & 0,10 & 0,03 & 0,04 & 0,37 & 0,61 & 0,12 & 0,204 \\
\hline Biaya yang Terjangkau & 0,10 & 0,69 & 0,41 & 0,41 & 0,10 & 0,09 & 0,24 & 0,10 & 0,11 & 0,70 & 0,09 & 0,26 & 0,13 & 0,12 & 0,31 & 0,257 \\
\hline $\begin{array}{l}\text { Mengoptimalkan Sarana dan } \\
\text { Prasarana yang dimiliki } \\
\text { Perguruan Tinggi }\end{array}$ & 0,04 & 0,20 & 0,36 & 0,36 & 0,04 & 0,03 & 0,64 & 0,10 & 0,10 & 0,10 & 0,22 & 0,41 & 0,35 & 0,21 & 0,52 & 0,245 \\
\hline$C R$ & 0,29 & 0,40 & 0,03 & 0,03 & 0,31 & 0,36 & 0,34 & 0,52 & 0,59 & 0,57 & 0,36 & 0,38 & 2,57 & 0,20 & 0,49 & 0,50 \\
\hline
\end{tabular}

Sumber : Hasil Data Primer Yang Telah Diolah Penulis (2016) 
Berdasarkan data-data dan perhitungan dari hasil penilaian responden atas kuisioner AHP tersebut, maka diperoleh hasil urutan prioritas berdasarkan nilai prioritas tertinggi ditampilkan pada tabel 4.2.

Tabel 1.3 Hasil Pengolahan AHP Dengan Skenario Optimis

\begin{tabular}{clc}
\hline LEVEL & \multicolumn{1}{c}{ DEFINISI } & BOBOT LOKAL \\
\hline 1 & Skenario & \\
\hline & Optimis & 0,627 \\
\cline { 2 - 3 } & Status Quo & 0,213 \\
\cline { 2 - 3 } & Pesimis & 0,163 \\
\hline 2 & Sasaran & 0,163 \\
\hline & Meningkatkan Kualitas Output & 0,504 \\
\cline { 2 - 3 } & Meningkatkan Sarana Prasarana Kegiatan Belajar & 0,383 \\
\cline { 2 - 3 } & Mengajar & 0,507 \\
\cline { 2 - 3 } 3 & Meningkatan Pendapatan/Profit & 0,363 \\
\hline & Strategi & 0,224 \\
\cline { 2 - 3 } & Meningkatkan Keterampilan Manajerial Input & 0,203 \\
\cline { 2 - 3 } & Menumbuhkan Pangsa Pasar/Pemasaran & \\
\cline { 2 - 3 } & Perguruan Tinggi & \\
\cline { 2 - 3 } & Biaya yang Terjangkau & \\
\hline
\end{tabular}

Sumber : Hasil Data Primer

Dari Tabel 1.3 dapat disimpulkan bahwa kondisi pendidikan di kota Jakarta khususnya Pendidikan Tinggi, adalah dalam kondisi OPTIMIS, dengan sasaran yang harus diprioritaskan adalah "Meningkatkan Sarana Prasarana Kegiatan Belajar Mengajar". Hal ini berarti bahwa diperkirakan kondisi pendidikan khususnya di DKI Jakarta akan mengalami perkembangan yang lebih baik dibandingkan saat ini. Untuk mencapai perkembangan positif tersebut akan menghadapi berbagai tantangan dari kemajuan tersebut, maka urutan prioritas kebijakan yang bisa dilakukan oleh pemerintah dan pihak manajemen pendidikan tinggi dapat digambarkan dalam tabel sebelumnya.

1. Kebijakan Strategi Peningkatan Minat Masyarakat Terhadap Produktivitas Pendidikan Tinggi

Dalam rangka meningkatkan kualitas output pendidikan tinggi, menurut hasil penilaian responden, sasaran yang harus diprioritaskan adalah "Meningkatkan Sarana Prasarana Kegiatan Belajar Mengajar". Hal ini sesuai dengan fakta bahwa kondisi pendidikan tinggi di Indonesia sudah mengikuti perkembangan zaman dan dapat bersaing dengan kondisi pendidikan di negara-negara maju dan berkembang lainya di sekitar wilayah Indonesia. Namun di balik majunya peradaban pendidikan di Indonesia, masih banyak terdapat beberapa Pendidikan Tinggi baik Pendidikan Tinggi Negeri maupun swasta yang belum memiliki sarana prasarana khususnya dalam kegiatan belajar mengajar yang belum memadai yang mendukung dalam menciptakan kualitas pendidikan tinggi tingkat nasional hingga internasional. Berdasarkan pengolahan data menggunakan metode AHP, untuk mencapai "Meningkatkan Sarana Prasarana Kegiatan Belajar Mengajar" dari berbagai pendidikan tinggi, didapatkan prioritas strategi kebijakan meningkatkan minat masyarakat terhadap produktivitas pendidikan tinggi khususnya di DKI Jakarta sebagai berikut :

\section{a. Meningkatkan Keterampilan Manajerial Input(Rektorat,Dosen,Karyawan). (Prioritas I)}

Dengan semakin bertumbuhnya perekonomian di Indonesia mengakibatkan meningkatnya permintaan terhadap tenaga ahli lulusan dari universitas negeri dan swasta. Hal ini tidak dapat dipenuhi sepenuhnya oleh perguruan tinggi negeri. Kementerian Riset dan Pendidikan Tinggi membuka kesempatan bagi yayasan, perorangan, pemerintah daerah membuka perguruan tinggi swasta. Namun pesatnya pertumbuhan pendidikan tinggi negeri dan swasta ini tidak disertai dengan terpenuhinya sarana prasarana kegiatan belajar 
mengajar seperti kelas, laboratorium, perlengkapan dan peralatan laboratorium, Sistem Informasi Manajemen yang diperuntukan mengolah bank data Dosen, Karyawan, dan Mahasiswa yang efektif dan efisien dari masingmasing perguruan tinggi khususnya perguruan tinggi swasta. Hal ini disebabkan masih rendahnya kualitas Input dari masing-masing pendidikan tinggi. Berdasarkan pemikiran tersebut, maka Ditjen Dikti secara sungguhsungguh melakukan pembinaan mutu PTN dan PTS secara intensif. Usaha yang menonjol antara lain melalui pembenahan masukanmasukan instrumental yang menentukan mutu, di antaranya meningkatkan mutu dosen, membenahi sistem pengendalian mutu melalui instrumen-instrumen seperti sistem evaluasi, melakukan akreditasi melalui Badan Akreditasi Nasional Pendidikan Tinggi (BAN-PT) bagi pihak manajemen rektorat dan karyawan dari tiap-tiap pendidikan tinggi, dan lain-lain. Peningkatan mutu dosen dilakukan dengan mendorong para dosen untuk melakukan studi lanjut baik di dalam negeri maupun di luar negeri. Untuk pendidikan di dalam negeri Ditjen Dikti mendorong perguruan tinggi yang sudah memiliki tenaga dosen yang memiliki syarat dan kualitas tertentu untuk mendirikan program pascasarjana. Program pascasarjana inilah yang akan mendidik dosen-dosen pada jenjang S2 dan S3, terutama untuk dosen-dosen yang tidak memiliki kesempatan belajar di luar negeri.

Sesuai dengan Tridharma Perguruan Tinggi, salah satu rumusannya adalah bahwa perguruan tinggi merupakan pusat riset dan pengembangan ilmu pengetahuan. Untuk mendukung riset-riset di perguruan tinggi Ditjen Dikti dan pihak rektorat (sesuai dengan kemampuan dan kualitas output dari tiap-tiap pendidikan tinggi) menciptakan berbagai program, baik berupa program pembiayaan riset secara kompetitif, berbagai pelatihan, maupun berbagai penyediaan fasilitas riset. Hibah-hibah penelitian dan pengabdian kepada masyarakat ditawarkan kepada seluruh dosen, baik dosen PTN maupun dosen PTS. Dengan model semacam ini para dosen dipacu untuk berlombalomba melakukan penelitian baru untuk pengembangan ilmu pengetahuan sesuai bidang masing-masing. Untuk lebih meningkatkan kemampuan meneliti maka dilakukan kerjasama antara perguruan tinggi dengan lembaga riset di dalam negeri dan di luar negeri. Di dalam negeri kerjasama riset dilakukan dengan Lembaga Ilmu Pengetahuan Indonesia (LIPI), Kementrian Riset dan Teknologi beserta lembaga yang ada di bawahnya, serta pusat-pusat penelitian yang berada di bawah kementrian lain. Kerja sama dengan universitas di dalam dan luar negeri dilakukan dalam kerangka penelitian bersama.

\section{b. Menumbuhkan pangsa pasar/pemasaran}

(Prioritas II)

Indonesia yang memiliki penduduk mencapai 259,9 juta jiwa merupakan pangsa pasar yang besar bagi pendidikan tinggi. Hal inilah yang menyebabkan sebagai peluang dan ancaman bagi pendidikan tinggi di Indonesia. Banyaknya berbagai perguruan tinggi asing baik dari negara tetangga Asia Tenggara, Asia, Eropa, Amerika, dan Australia menawarkan berbagai keunggulan dan fasilitas yang mereka miliki untuk ditawarkan kepada pasar pendidikan tinggi di Indonesia. Oleh karena itu perguruan tinggi Indonesia dalam negeri baik negeri maupun swasta harus terus berbenah, baik secara kualitas maupun kuantitas karena seleksi alam juga berlaku pada dunia pendidikan. Bagi yang tidak berkualitas secara perlahan-lahan akan ditinggalkan. Selain persaingan dari berbagai pendidikan tinggi dari negara asing, terdapat persaingan di antara lebih dari 2.600-an PTS sendiri, PTS juga terancam oleh perguruan tinggi negeri yang membuka berbagai program masuk universitas negeri yang dosen dan fasilitasnya dibiayai negara,

Menurut salah satu responden, sistem yang paling efektif untuk merebut dan mempertahankan pangsa pasar pendidikan di Indonesia adalah Manajemen Pendidikan Tinggi yang ditingkatkan secara berkelanjutan guna memastikan kepuasan pelanggan tercapai pada setiap tahapan interaksi dengan universitas khususnya dalam hal Pendidikan dosen, pengalaman dosen, modal sosial, sarana prasarana dan teknologi yang dimiliki. Dalam arti luas, kepuasan itu sesungguhnya merupakan modal perguruan tinggi untuk menciptakan 'getok-tular' dari mulut ke mulut (word-ofmouth) yang positif dari satu orang kepada orang lain.

\section{c. Mengoptimalkan Modal/sarana dan prasarana yang telah dimiliki oleh LembagaPendidikanTinggi. \\ (Prioritas III)}

Perkembangan lingkungan eksternal dan internal menuntut pengelolaan aset prasarana dan sarana fisik tiap pendidikan tinggi yang dilakukan secara strategis. Cara pandang terhadap aset prasarana dan sarana akademik 
perlu diarahkan ke dalam satu cara pandang yakni, seluruh prasarana dan sarana aset pendidikan tinggi harus dijadikan sebagai prasarana dan sarana untuk mencapai visi serta misi pendidikan tinggi sebagaimana ditetapkan dalam Rencana Strategis di tiap perguruan tinggi. Pengelolaan prasarana dan sarana adalah salah satu subsistem dan sebagai turunan dari Penjaminan Mutu (Quality Assurance) pendidikan tinggi. Selain itu pengelolaan prasarana dan sarana memiliki keterkaitan sangat erat dengan sistem Monitoring dan Evaluasi Internal (MONEVIN) Pendidikan Tinggi. Pengelolaan prasarana dan sarana akademik juga memiliki fungsi yang terintegrasi dengan subsistem lain dalam pengelolaan berbagai sumber pelayanan akademik Pendidikan Tinggi.

Manajemen Sarana dan Prasarana di lingkungan Pendidikan Tinggi dilandasi oleh hasrat bahwa Sarana dan Prasarana yang dimiliki diupayakan selalu terjaga keamanannya, terpelihara dengan baik, mengalami perbaikan dalam pengelolaannya, dan peningkatan kualitas pemanfaatannya. Pengelolaan prasarana dan sarana fisik di Pendidikan Tinggi mencakup fungsi: pengadaan, inventarisasi, legal audit, penilaian, operasi, pemeliharaan, pengawasan dan pengendalian, pengalihan, dan penghapusan Sarana dan Prasarana. Seluruh fungsi di atas didasari peraturan dan pedoman umum, SOP serta standar pengelolaan Sarana dan Prasarana yang bersangkutan. SOP ini diharapkan dapat membantu para pelaksana pengelolaan prasarana dan sarana akademik, bagi para pelaksana teknis serta para pengguna fasilitas fisik berupa prasarana dan sarana di lingkungan Pendidikan Tinggi. Dengan makin baiknya pengelolaan prasarana dan sarana, maka akan sangat besar kontribusinya bagi peningkatan minat masyarakat dan produktivitas pendidikan berupa Meningkatnya Kualitas Output (Wisudawan dan Wisudawati) di Pendidikan Tinggi tersebut.

Melalui UU. No. 12 Tahun 2012 Pasal 88 tentang Pendidikan Tinggi yang dijadikan 'senjata ampuh' untuk membuat kebijakan yang mengatur pembiayaan pertisipasi masyarakat terhadap Perguruan Tinggi, yakni kebijakan Uang Kuliah Tunggal (UKT). Kegamangan menghiasi kebijakan UKT dikarenakan adanya ketidakjelasan hukum. Pasal ini tidak memberikan jaminan hak rakyat atas Pendidikan Tinggi. Apalagi dalam ayat (3) terdapat frasa "...digunakan sebagai dasar oleh Perguruan Tinggi untuk menetapkan biaya yang ditanggung oleh Mahasiswa" yang memberikan keleluasaan Perguruan Tinggi untuk menentukan biaya yang ditanggung oleh Mahasiswa. Pasal ini juga berpotensi menutup akses rakyat yang kurang mampu secara financial untuk dapat menikmati Pendidikan Tinggi. atau dapat disederhanakan dalam hirarki menjadi Biaya yang terjangkau...........................(Prioritas IV)

\section{SIMPULAN DAN SARAN}

\section{Simpulan}

Berdasarkan hasil penelitian yang telah dilakukan oleh penulis maka dapat disimpulkan bahwa kondisi pendidikan khususnya Pendidikan Tinggi adalah dalam kondisi OPTIMIS. Hal ini berarti bahwa diperkirakan kondisi pendidikan di DKI Jakarta khususnya akan mengalami perkembangan yang lebih baik dibandingkan saat ini. Untuk mencapai perkembangan positif tersebut akan menghadapi berbagai tantangan dari kemajuan tersebut, Prioritas strategi yang terbaik dalam rangka meningkatkan minat masyarakat terhadap pendidikan guna mencapai produktivitas pendidikan di masa yang akan datang adalah sebagai berikut :

a. Meningkatkan Keterampilan Manajerial Input (Rektorat, Dosen, Karyawan)

b. Menumbuhkan pangsa pasar/pemasaran

c. Mengoptimalkan Modal/sarana dan prasarana yang telah dimiliki oleh Lembaga Pendidikan Tinggi

d. Perguruan Tinggi menetapkan biaya Terjangkau oleh berbagai kalangan masyarakat baik di kalangan menengah ke atas maupun menengah ke bawah.

Prioritas strategi ini sangat mungkin berubah, terutama apabila terjadi hal-hal yang diluar rencana. Apabila skenario yang paling realistis adalah skenario status quo, maka sasaran yang harus dicapai adalah "Meningkatkan sarana prasarana kegiatan Belajar Mengajar", dengan prioritas pertama yang harus dilakukan adalah "Meningkatkan Keterampilan Manajerial Input (Rektorat, Dosen, dan Karyawan)". Sedangkan apabila skenario yang dianggap paling realistis adalah skenario pesimis, maka sasaran yang harus dicapai adalah sasaran yang menjadi prioritas adalah Meningkatkan Kualitas Output 
Pendidikan tinggi (Wisudawan/Wisudawati), dengan kebijakan yang harus dilakukan oleh Pemerintah dan pihak manajemen Pendidikan Tinggi adalah Meningkatkan Keterampilan Manajerial Input (Rektorat, Dosen, dan Karyawan).

\section{Saran}

1. Perlu dilakukan pendampingan bagi responden oleh penulis. Hal ini dikarenakan penggunaan metode AHP juga memiliki kelemahan. model AHP tidak luput dari beberapa kelemahan yang dapat berakibat fatal. Ketergantungan model ini pada input berupa persepsi seorang expert akan membuat hasil akhir dari model ini menjadi tidak ada artinya apabila expert memberikan penilaian yang keliru. Kondisi ini ditambah dengan belum adanya kriteria yang jelas untuk seorang expert, membuat orang sering ragu-ragu dalam menanggapi solusi yang dihasilkan model ini.

2. Menambahkan responden yang lebih variatif, misalnya dengan menambahkan pelaku pendidikan dari berbagai usia, profesi, tingkat taraf hidup masyarakat, dan lainnya.

\section{REFERENSI}

(2002). Annual Report

2001. PT.Astra International Inc., Jakarta. (2001). Astra - a Green Company with Sustainable Business Practices, PT.Astra International Inc., Jakarta.

Fagence, Michael. (1977). Citizen Participating in Planning, Oxford: Pergamon.

Notoatmodjo, Soekidjo. (2003). Pendidikan dan Perilaku Kesehatan. Jakarta. PT. Rineka Cipta

Sato, Yuri. (1993). The Astra Group : A Pioneer for Management Modernization In Indonesia.

Shaharudin, Mohd Rizaimy, Wan Mansor, Suhardi, Abu Hassan, Anita, Wan Omar, Maznah and Harniza Harun, Etty.(2013). The relationship between product quality and purchase intention: The case of Malaysia's national motorcycle/scooter manufacturer. Faculty of Business Management, University of Teknologi MARA.Merbok, Kedah, Malaysia
Thomas L. Saaty, (1993). Pengambilan Keputusan Bagi Para Pemimpin. Seri Manajemen No. 134, PT. Pustaka Binaman Pressindo, Jakarta. .(2003). Undang - Undang Republik Indonesia Nomor 20 Tahun 2003 Tentang Sistem Pendidikan nasional.

(1992). Peraturan Pemerintah No 39 tahun 1992 Tentang Peran Serta Masyarakat Dalam Pendidikan Nasional.

(2015). Inilah Penyebab rendahnya kualitas perguruan tinggi di Indonesia. Retrieved September 20th 2015.Website:http://m.monitorday.com/d etail/6321/inilah-penyebab-rendahnyakualitas-perguruan-tinggi-di-Indonesia.

BPS Republik Indonesia. (2015). Link Tabel Statis. Retrieved January 19th 2016. Website:http://bps.go.id/linkTabelStatis/vi ew/id/1839.

Setiawati, L. (2010). Efektivitas Pengembangan Manajemen Pendidikan Tinggi (Studi pada Perguruan Tinggi Negeri di Jawa Barat Menuju World Class University). Retrieved November 11th 2017. Website: http://jurnal.upi.edu/file/5_Linda_setiawat i.pdf

Musnaini, Harniza Harun. (2013). Faktor-faktor Yang Mempengaruhi Manajemen Mutu Terpadu Pada Produktivitas Pendidikan Tinggi di Jambi. Retrieved September 20th 2015. Website : www.academia.edu/11210017/faktorfaktor_yang_mempengaruhi_manajemen_ mutu_terpadu_pada_produktivitas_pendid ikan.

Subardo, R. (2015). Rendahnya Kualitas Universitas di Indonesia. Retrieved September 20th 2015, Website : http://m.kompasiana.com/rakasubardo/ren dahnya-kualitas-universitas-diindonesia_552058b4813311247419f7b2 .

Soni, A. Nulhaqim, Dudi Heryadi, dan Ramdhan Pancasilawan. (2015). Peranan Perguruan Tinggi Dalam Meningkatkan Kualitas Pendidikan di Indonesia Untuk Menghadapi ASEAN Community 2015 : Studi Kasus Universitas Padjajaran. Retrieved 11th November 2017. Website : http://pustaka.unpad.ac.id/wpcontent/uploads/2015/04/9-Perananperguruan-tinggi-dalam-meningkatkankualitas-pendidikan.pdf 
